\title{
ACCESS TO SOCIAL SECURITY FOR NON-CITIZENS: AN INTERNATIONAL, SOUTH AFRICAN AND EUROPEAN VIEW
}

\author{
by Taryn Lee Vos*
}

\section{Introduction}

South Africa has become a magnet to a larger group of foreign migrants than the global average. ${ }^{1}$ This is due to the fact that it is a front-runner, economically speaking, in Sub-Sahara Africa with a reputation of political stability. ${ }^{2}$ The South African Constitution ${ }^{3}$ is the supreme law of the Republic, to which all other law is subject. South Africa's constitutional framework, coupled with immigration legislation and policies, aim to promote the rights enshrined in the Bill of Rights ${ }^{4}$ for all individuals living within the borders of the Republic. ${ }^{5}$ While certain rights are expressly reserved for citizens only and are largely of a civil or political nature, the remaining rights are those that 'everyone', including foreign nationals, may enjoy. Non-citizens within the borders of the Republic receive, inter alia, the protection of South Africa's basic constitutional values; in particular the right to equality, human dignity and freedom. Socio-economic rights, subject to the limitations clause in section 36 of the Constitution, are also made available to everyone. This includes both citizens and foreign nationals. These rights can be found in section 25, 26, 27, 28 and 29 of the Constitution and relate to issues of access to land, housing, health care, food, social security and education.

The focus of this paper will be the right of access to social security for non-citizens, particularly migrants, in South Africa. Who falls within the scope of the term 'everyone' as found in section 27 of the Constitution? The international perspective on the issue of social exclusion of non-citizens from accessing social security benefits is

* Final year LLB student, University of Stellenbosch. I acknowledge with thanks the assistance and wisdom of Professor Henk Botha (University of Stellenbosch).

1 International Federation for Human Rights (FIDH) International Federation for Human Rights Report 'Surplus People? Undocumented and other vulnerable migrants in South Africa' (2008) 8.

International Federation for Human Rights (n 1 above) 8.

Constitution of the Republic of South Africa, 1996 ('the Constitution').

Ch 2 of the Constitution.

Sec 7(2) of the Constitution. 
briefly dealt with, followed by a discussion of the South African perspective on the matter. The approach of the South African Constitutional Court in respect of the protection of the rights of noncitizens will then be discussed. The European approach to the matter, including the approach of European courts, will then be examined. The concluding paragraphs entail an evaluation of the improvements that can be made to the South African social security system as inspired by the European approach.

\section{Social security: a conceptual view}

The right of access to social security as envisaged in section 27 of the Constitution is available to 'everyone' (regardless of nationality) and includes access to the appropriate social assistance should anyone be unable to support themselves or their dependants. Social security ${ }^{6}$ consists primarily of social insurance and social assistance. ${ }^{7}$ The social insurance system in South Africa is relatively well-developed ${ }^{8}$ and provides benefits to those in formal employment, for example, unemployment insurance and worker's compensation. Social assistance, on the other hand, has a more strict and exclusive scope (especially the grant system) and provides benefits according to a categorical, means-tested standard. The definition of social security is not a rigid one and varies according to the characteristics of each country. ${ }^{9}$

\section{The international perspective}

The right to social security has a certain universality since it presupposes that those who find themselves in a vulnerable situation should be protected due to their membership to society. Access to social security and protection of non-citizens is a problematic issue, largely due to the tensions between social security and redistribution and the fact that conventional social insurance systems are employment-based. Consequently social security can be a discriminating matter. ${ }^{10}$ Without international protection noncitizens, especially migrant workers, find themselves at risk of

D Kasente 'Gender and social security reform in Africa' (2000) 53 International Social Security Review 27 30. The concept of social security is ill-defined, but according to Kasente can be used to include the 'totality of organisational forms through which goods and services are provided to people in situations of need and distress when they cannot achieve security by their own individual means.'

7 The modern approach to social security is distinct from the broader concept of 'social protection' which refers to a system of welfare support.

8 A Dekker et al 'Social security: a conceptual view' (2000) 4 Law, Democracy \& Development 12.

9 Dekker et al (n 8 above) 2 - 4.

10 U Becker \& MP Olivier Access to social security for non-citizens and informal workers: An international, South Africa and German perspective (2008) xiii. 
exclusion from accessing social security in both their home and host nations. ${ }^{11}$ Article 2 of the Equality of Treatment (Accident Compensation) Convention 19 of 1925 and article 8 of the Equality of Treatment (Social Security) Convention 118 of 1962 ('Convention $\left.118^{\prime}\right)$ are examples of international instruments that have set certain standards regarding the social security plight of non-citizens. Convention 118 allows for a certain period of residence to be prescribed for the receipt of certain benefits. ${ }^{12}$ The Minimum Standards of Social Security Convention ${ }^{13}$ is authority for the equal treatment of citizens and non-citizen residents with regards to social insurance schemes. This Convention allows for the exclusion of noncitizens where benefits or part of the benefits are payable entirely from public funds (tax-funded or non-contributory social security benefits).

The large majority of social security conventions do leave room for flexibility with regards to social assistance access for non-citizens. Article 6 of the Migration for Employment Convention ${ }^{14}$ prohibits discriminatory treatment between 'immigrants lawfully within its territory' and nationals with regards to trade union rights, accommodation rights, employment rights and social security rights. The Migrant Workers Convention ${ }^{15}$ provides that states should commit themselves to advance and guarantee

equality of opportunity and treatment in respect of employment and occupation, of social security, of trade union and cultural rights of individual and collective freedoms for persons who as migrant workers or as members of their families are lawfully within its territory. ${ }^{16}$

The inclination to provide rights to non-citizens lawfully residing within the territory of a host nation is evident.

\section{The South African perspective}

Universal access to social security and an adequate standard of living can be regarded as both a fundamental human right and a policy objective in South Africa. Section 27 of the Constitution not only guarantees 'everyone' the right of access to social security but also imposes a duty on the state to take reasonable legislative and other measures, within the available resources, to achieve the progressive realisation of this right. The laws, regulations and rules that govern social security do not always offer solid answers regarding eligibility

Becker \& Olivier (n 10 above) 7.

Art 4(2) of Convention 118 excludes sickness benefit, employment injury benefit, medical care and family benefit from this requirement.

ILO 102/1952.

ILO 97/1949.

ILO 143/1975.

Becker \& Olivier (n 10 above) $23-25$. 
to social security benefits. The short-comings in the social security system often result in the exclusion of the marginalised. ${ }^{17}$

Generally speaking non-citizens are excluded from social security protection especially when it comes to social assistance. The Social Assistance Act13 of 2004 (the 'Social Assistance Act') is the most comprehensive instrument regulating social assistance. ${ }^{18}$ South African citizenship is an eligibility requirement in order to receive access to the large majority of social assistance benefits. Section 5(c) of the Social Assistance Act specifically restricts social grants to South African citizens. The Constitutional Court in Khosa and Others $v$ Minister of Social Development and Others; Mahlaule and Others $v$ Minister of Social Development and Others ${ }^{19}$ ('Khosa') has, however, extended the scope of the Social Assistance Act and held that permanent residents are entitled to access to social assistance grants. A means test must be complied with in order to receive access to the grants.

Certain groups of non-citizens do enjoy full legal protection including rights as set out in chapter 2 of the Constitution. Those who have gained refugee status ${ }^{20}$ enjoy the section 27 socio-economic rights. This would include the right of access to social security and the suitable social assistance in situations where the refugees are incapable of supporting themselves and those dependent on them. Despite this protection the Social Assistance Act does not include refugees in its scope of protection. The two Acts appear to be in conflict with one another. ${ }^{21}$ Section 2(1) of the Social Assistance Act also provides that where a bilateral agreement exists between SA and a non-citizen's country of origin that non-citizen will receive coverage. These bilateral agreements do not include international instruments.

\subsection{International influence on the South African position}

Arguably the most comprehensive and contentious international instrument is the International Convention on the Protection of Rights of All Migrant Workers and Members of their Families. ${ }^{22}$ The purpose of the Convention is to extend social protection to migrants and their families, including those that are irregular or undocumented migrants. In the absence of discrimination based on status, access to social security is one of the rights guaranteed to all migrants under

Becker \& Olivier (n 10 above) 60.

As above.

20046 SA 505 (CC).

Refugees Act 130 of $1998 \mathrm{sec} 3(\mathrm{a})$.

'Comparative review of the position of non-citizen migrants in social security'

Report for the South African Treasury (2004) 39- 40.

22

GA Res 45/158. 
this Convention. Several states, including South Africa, have not ratified or signed this Convention in the fear that it may encourage irregular migration. ${ }^{23}$ Regardless, the basic principles of equality and human rights are respected in South Africa through the adherence to international human rights law. South Africa has also committed itself to the protection of all foreign children's right of access to social protection through the ratified Convention of the Rights of Children. ${ }^{24}$

South Africa has also ratified several other international agreements that require a commitment to advancing the right of access to social security for non-citizens including the Universal Declaration of Human Rights $(1948)^{25}$ - which states that everyone, as a member of society, is entitled to social security - and the United Nations Declaration on the Human Rights of Individuals who are not Nationals of the Country in which they Live (1985). ${ }^{26}$ Although South Africa has little involvement in social security agreements its rightsbased approach has been effective, to a degree, in protecting the right of access to social security of non-citizens. ${ }^{27}$

\subsection{The position of migrants according to the Constitutional Court}

The judgement in Khosa played a key role in improving access to social assistance for migrants who are permanent residents of South Africa. The constitutionality of certain provisions of the Social Assistance Act 59 of 1992 (the Act) were challenged by Mozambican citizens (permanent residents of South Africa) who were excluded from social assistance. They would have been entitled to social assistance under the Act but for the requirement of citizenship. The applicants argued that their exclusion was contrary to the state's duties under section 27(1)(c) of the Constitution. They also claimed that their section 9 right to equality had been limited and could not be justified in terms of the section 36 general limitations clause of the Constitution. It was held that the Bill of Rights protects the rights of 'all people in our country' and that section 27 of the Constitution does provide that everyone has the right of access to social security. ${ }^{28}$ Section $27(1)$ showed no indication that the right was restricted to citizens alone.

AH Dekker'The social protection of non-citizen migrants in South Africa' (2010) 22 SA Mercantile Law Journal 388-392.

UN General Assembly Document A/RES/44/25. This Convention was ratified on 16 June 1995.

GA res 217A (III) UN Doc A/810 71.

GA res 40/144, annex, 40 UN GAOR Supp (No. 53) 252, UN Doc A/40/53.

Becker \& Olivier (n 10 above) 10

Sec 27(2) also imposes a duty on the state to take reasonable legislative and other measures, within the available resources, to achieve the progressive realisation of this right as mentioned in paragraph 4. 
The term 'everyone', as found in the provision, included both citizens and non-citizens. ${ }^{29}$

The Court found it reasonable to exclude certain non-citizens from this entitlement, for example, workers who were citizens of another country, illegal residents and visitors. Permanent residents were included as their link to the country was not feeble. It was felt that denying permanent residents social security would be an attack on their constitutional right to equality, human dignity and freedom. ${ }^{30}$ The state tried to argue that extending social security to non-citizen permanent residents would create an enormous burden on the state. This argument failed in light of the fact that the additional costs would equate to two percent of the overall government expenditure on social grants. The Court held:

If a mistake is made in this regard, and the permanent resident becomes a burden, that may be a cost we have to pay for the constitutional commitment to developing a caring society, and granting socio-economic rights to all who make their homes here. ${ }^{31}$

The Court felt that the appropriate remedy would be to read the words 'or permanent residents' into the provision in question. ${ }^{32}$

\subsubsection{Concerns regarding the judgment in Khosa}

This judgement has been subject to criticism. The respondents averred that the exclusion of permanent residents was consistent with the immigration policy of South Africa. They claimed that the immigration policy 'seeks to exclude persons who may become a burden on the state and thereby to encourage self-sufficiency among foreign nationals.' 33 These averments were echoed by Alexander Graser. With reference to the minority judgement, Graser expressed three areas of concern. Firstly, he feared that the social security system would be unduly burdened by the extra costs. Secondly, the increased availability of access to social security would act as a magnet pulling more permanent residents into the country, thereby increasing the burden even more. He referred to this as the 'welfare magnet argument'. Thirdly, Graser feared that the current level of

29 Paras 46-47.

30 Government of the Republic of South Africa \& Others $v$ Grootboom \& Others 2000 11 BCLR 1169 (CC); socio-economic rights in the Constitution were said to be closely linked to the fundamental values of human dignity, equality and freedom.

31 Para 65.

32 It was also held that sec 28(1)(c) of the Constitution would be violated should disadvantaged children be excluded from the scope of social assistance due to their parent's nationality. The United Nations Convention on the Rights of the Child (1989) as ratified by South Africa places an obligation on South Africa to provide access to social security to disadvantaged children.

Para 63. 
benefits would decrease as a result of the increased burden on the welfare budget. ${ }^{34}$

The majority judgement dealt with the first issue by concluding that the respondents were unable to present an exact number of noncitizens who currently fell within permanent resident status or the number that would be eligible for social assistance. The Court also estimated that the additional costs would amount to a small percentage of the overall government spending as mentioned above. The second issue has been referenced to in similar proceedings internationally, for example Germany ${ }^{35}$ and the United States of America (US). After the 1969 ruling of the Supreme Court in the US ${ }^{36}$ certain welfare benefits were extended to migrants from other states within the US. A fear arose that more generous states would become a magnet for beneficiaries. Predictably, the benefit levels decreased but the insignificant number of interstate migrants that were eligible for the welfare benefits resulted in negligible migration. The 'welfare magnet argument' appeared to have failed in this case. The third issue can be addressed by referring to the condition for entitlement to social assistance. The South African government would retain control regarding the number of non-citizens who qualify as permanent residents and in this way would have a measure of control over the possible increase in welfare spending. ${ }^{37}$

\subsubsection{The limitation of socio-economic rights and the role of section 36 of the Constitution}

In Soobramoney $v$ Minister of Health, Kwazulu-Natal ${ }^{38}$ the Court acknowledged that:

We live in a society in which there are great disparities in wealth. Millions of people are living in deplorable conditions and in great poverty. There is a high level of unemployment, inadequate social security, and many do not have access to clean water or to adequate health care services. ${ }^{39}$

The majority reiterated the commitment made in the preamble of the Constitution to '[i]mprove the quality of life for all citizens." 40 This

34 A Graser ' Taking inclusion seriously, An outside perspective on Khosa and Others $\checkmark$ Minister of Social Development and Others; Mahlaule and Others v Minister of Social Development and Others (decision of the Constitutional Court of South Africa)' in U Becker \& MP Olivier (eds) Access to social security for non-citizens and informal workers: An international, South Africa and German perspective (2008) 163.

35 German Constitutional Court (BverfG) Decision of 6 July 2004 case numbers (Az.): 1 BvL 4/97 1 BvL 5/97 1 BvL 6/97.

Shapiro $v$ Thompson 394 US 618 (1969).

Becker \& Olivier (n 10 above) 165 - 169.

19981 SA 765 (CC).

Para 8.

Para 9. 
may be an indication that when it comes to the progression of realisation of socio-economic rights citizens will be treated more favourably than non-citizens even though these rights, in principle, apply to 'everyone'. 41

Professor Liebenberg advocates for the necessity of utilising the general limitations clause analysis when dealing with the socioeconomic rights. Liebenberg's views regarding the limitation of a right are relevant within the context of the Khosa case. Liebenberg feels that the justification for the limitation of a right by the state should not be solely based on convenience, cost-saving or a reprioritisation of resources. It is argued that to permit these grounds as sufficient justification for limitation would result in the rights becoming devoid of all effect. The state would have to show that due to limited resources the limitation is required for the sake of general welfare in a democratic society based on human dignity, equality and freedom. ${ }^{42}$

\section{The European Union perspective: from citizenship to legal residence as a requirement}

\subsection{Access to social security for non-European Union citizens}

The European Union (EU) has adopted a similar attitude to the one set out in the Khosa judgement with regards to a more inclusive social security system. Citizenship as a sole requirement is no longer regarded as appropriate for the exclusion of certain persons from their right of access to social security. Consequently, citizen tests are no longer acceptable and there has been a movement towards a legal residence criteria. It is not clear what is meant by this concept but it appears as though 'legal residence' would extend the right of access to social security further than that of the Khosa judgement since it is not restricted to permanent legal residence only. ${ }^{43}$ The exclusion of certain individuals from the South African social security system must pass the constitutional test of reasonableness. The consideration of international law and foreign law could potentially assist courts in this evaluation.

41 M Pieterse 'Foreigners and socio-economic rights: Legal entitlements or wishful thinking?' (2000) 63 Tydskrif vir Hedendaagse Romeins-Hollandse Reg 5159.

42 S Liebenberg 'Violation of socio-economic rights: The role of the South African Human Rights Commission' in $\mathrm{P}$ Andrews \& $\mathrm{S}$ Ellmann (eds) The post-apartheid constitutions: Perspectives on South Africa's basic law (2001) 405424.

43 Olivier (n 21 above) 55. 


\subsubsection{European Court of Human Rights - jurisprudence}

The European Court of Human Rights (ECHR) decision in Gaygusuz v. Austria (Gaygusuz case) ${ }^{44}$ demonstrates the more inclusive approach mentioned above. The applicant was a Turkish national who had been living and working in Austria. When he became unemployed he qualified for an unemployment benefit. After the expiry of this benefit he approached the Arbeitsamt in Linz for emergency assistance. His case was brought before the Court of Human Rights after his claim was rejected on the single basis that he lacked Austrian nationality. The applicant relied on the non-discrimination clause in article 14 of the European Convention on Human Rights accompanied by article 1 of the First Protocol. ${ }^{45}$ Unequal treatment would only be tolerated if objective and reasonable justification could be presented. The Court ruled that since the applicant had lived legally in Austria and had paid contributions, the refusal to grant him emergency assistance was a violation of article 14 of the European Convention on Human Rights. In the ECHR case of Koua Poirrez $v$ France (Koua Poirrez case), a social assistance allowance for disabled persons was denied by French authorities to a disabled, adopted child of Ivory Coast nationality due to his nationality. ${ }^{46}$ The ECHR concluded that this allowance fell within the ambit of the First Protocol. The refusal of the grant was thus regarded as unjustified discrimination.

\subsubsection{The legal residence test}

The current trend seems to indicate that the citizen test has been rejected and a more inclusive legal residence test is being adopted. In the European Court of Justice case of Sürül $v$ Bundesanstalt für Arbeit ${ }^{47}$ a Turkish woman permitted to stay in Germany in accordance with the immigration law did not possess a regular residence permit. The Court made reference to the association regime that existed between Turkey and the EU. According to this the denial of family allowances to Turkish nationals who are legally residing within an EU member state would be in violation of the principle of equal treatment. In both Gaygusuz and Koua Poirrez the Courts specifically made reference to the legal residence of the claimants in their host states. The concept of legal residence is also often expressly referred to in recently adopted international instruments guaranteeing equality of treatment and the right to social security. This is demonstrated in article 34(2) the Charter of Fundamental Rights of

(1997) 23 EHRR 364.

ETS 5; 213 UNTS 221

$40892 / 98$.

ECJ 4 May 1999, case 262/96, ECR 1999, 1210. 
the European Union, ${ }^{48}$ which refers to the right to social security for migrants travelling and moving within European territory. ${ }^{49}$

It would be erroneous to conclude that in Europe non-citizen migrants with temporary resident status enjoy complete access to social assistance. Temporary residents are admitted only if they meet the criteria of possessing sufficient means of subsistence and refrain from becoming a burden on public funds. Only those who reside legally within the state will be eligible for social assistance. Consequently, temporary residents with insufficient means may find themselves losing their residence status. This scenario would then exclude them from the right to social assistance. What can be safely concluded is that the European approach appears to tolerate the exclusion of non-citizens from social security systems should they lack a proper residence title under the relevant immigration law. ${ }^{50}$

\subsection{Access to social security for EU-citizens}

The EU is a valuable subject for a comparative study in that coordination has been established between the member states despite the diversity in their individual social security systems. EU citizens are entitled to complete and equal protection where social security is concerned and it is prohibited to treat EU citizens less favourably than national citizens. Complete access to social security includes access to benefits and insurances that are prohibited from being subject to nationality tests or any test that could be regarded as being indirect discrimination towards non-nationals. Certain exceptions must be noted. No access to social assistance is guaranteed, inter alia, where sufficient means of subsistence is a condition upon which the legality of residence is dependent. ${ }^{51}$ EU-nationals enjoy complete access to social assistance on condition that they possess permanent residence status. This status can be acquired after five years of residence.

Regulation (EEC) No $1408 / 71^{52}$ deals with the co-ordination of social security schemes and protects the social security rights of migrants with regards to social insurance and non-contributory benefits (excluding social assistance). This regulation applies to certain non-EU citizens as well. ${ }^{53}$ This means that non-EU citizens

487 December 2000.

49 Art 34(2) of the Charter: 'Everyone residing and moving legally within the European Union is entitled to social security benefits, and social advantages in accordance with Community law and practices'.

50 Olivier (n 21 above) $53-56$.

51 See Art 24(2) of Directive 2004/38/EC.

$52 \mathrm{~L} 149$ of 5 July 1971 . This regulation has been replaced by Regulation (EC) No $883 / 2004$ which came into effect on 1 May 2010. European Economic Area countries have not agreed to the new regulation. The new regulation will also not apply to third country nationals (i.e. non-European Economic Area).

53 See Art. 2 of the regulation which states which persons are covered by the regulation. 
moving within the Union are treated equally to EU citizens. This regulation does not cover third country nationals who have migrated to one member state without then continuing on to another member state. Therefore, this regulation applies in an intra-community manner. ${ }^{54}$ A similar approach can be found in article 34(2) the Charter of Fundamental Rights of the European Union.

\section{How the South African social security system can be improved}

\subsection{The introduction of a means of subsistence test}

In a recommendation to the South African Treasury Olivier suggested that the relevant legislative and administrative measures be taken to introduce a more European attitude to the granting of residence status. A means of subsistence test should be incorporated into immigration law to which the acquisition of a temporary or permanent residence permit should be subject. Should there be a failure to continue to meet the means of subsistence test the temporary permit should be withdrawn. As a result all lawful residents who have refrained from becoming a burden on the state will have enhanced access to social assistance grants. According to Olivier this should not have any significant repercussions for the South African Budget. ${ }^{55}$

\subsection{Southern African Development Community instruments ${ }^{56}$}

Regional agreements are key to achieving the level of co-ordination found in the EU. However, regional instruments can prove problematic for South Africa in the Southern African Development Community (SADC). There is inconsistency among the countries involved regarding economic and political stability and the quality of the social security systems. Consensus between the parties involved regarding fundamental values and minimum standards of social protection are essential to improving regional social security protection. Even though the SADC is a regional organisation and not a supra-national institution like the EU, similar principles seem to have been acknowledged and incorporated by the SADC for the improvement of social security protection on a regional level. The adoption of the principles set out in Regulation 1408/71 would assist in the equal treatment of citizens and non-citizens in SADC countries

Olivier (n 21 above) 53.

n 21 above 3.

For a comprehensive evaluation on access to social security within the SADC see $M$ Olivier 'Enhancing access to South African social security benefits by SADC citizens: The need to improve bilateral agreements within a multilateral framework' (2011) 1 SADC Law Journal 121. 
and would allow for the reaching of a consensus on certain vital principles. 57

It has been suggested that the status of SADC member states' citizens regarding social security should be developed in line with SADC goals of regional integration and unity. Policies should be developed where minimum standards for social protection of groups of beneficiaries are established, on the grounds of equality within the SADC regardless of citizenship status. ${ }^{58}$ Regional instruments such as the SADC Treaty and the Charter of Fundamental Social Rights in SADC have encouraged the establishment of a system of social security coverage for citizens of the different member states. These instruments impose a duty of member states to provide adequate social protection to workers in the region ${ }^{59}$ in the absence of a distinction between citizens and non-citizens. The Code on Social Security (2007) states that 'Everyone in SADC has the right to social security'.60 Social security in this case includes social insurance, social assistance and social allowances. It further states that

Everyone in SADC who has insufficient means of subsistence to support themselves and their dependents should be entitled to social assistance, in accordance with the level of socio-economic development in the particular Member State. ${ }^{61}$

This is a progressive step in the realisation of the right to social security for everyone within the region. South Africa is yet to fully make use of potential cross-border co-ordination arrangements to regulate the migration of citizens within the SADC. It has been argued that pure reciprocal arrangements similar to that found in the Social Assistance Act are inadequate when it comes to effectively regulating the position of migrating citizens of member states. ${ }^{62}$ Effective national legislation and multilateral arrangements will need to be adopted in order to ensure regional coverage and protection of social insurance benefits. This will assist in, not only, providing social security protection to migrant workers within the borders of SA but also migrant SA workers finding themselves away from home.

\subsection{The approach of the Courts}

The South African courts are empowered through section 38 of the Constitution to grant appropriate relief in situations where rights as enshrined in the Bill of Rights have been violated. Section 39(1)

R Holzman et al 'Portability Regimes of Pension and Health Care Benefits for International Migrants: An Analysis of Issues and Good Practices' (2005) 4 Social Protection Discussion 4 - 5.

58 Olivier (n 21 above) 72 - 73.

59 Art 10.1 of the Charter of Fundamental Social Rights in SADC.

60 Art 4.1.

61 Art 5.1.

62 Olivier (n 21 above) 72. 
requires that courts consider both international and foreign law when interpreting the Bill of Rights. When examining the international approach towards providing access to social security for non-citizens it would appear as though the position of South African courts falls short of broader international law standards where discrimination based on national or social origin constitutes a violation of human rights. ${ }^{63}$ This being said, it must be taken into account that certain international instruments provide flexibility for states to exclude certain groups of non-citizens in accordance with their resources and immigration policies. ${ }^{64}$ It was suggested that social assistance grants be made available to all lawful residents who have refrained from becoming a burden on the state. ${ }^{65}$ Although the Khosa judgement has directed the scope of access to social assistance in this direction, it is limited to permanent residents only, which is a less inclusive standard than the 'legally resident test' found in the EU. It may, at first, appear as though the South African courts have adopted a less liberal approach than countries who subscribe to the 'legally resident test'. However, when the access to social security for non-permanent residents is investigated, the potential risk of limited access exists as a result of the means of subsistence test in immigration law. ${ }^{66}$ In light of this, the position of the South African Constitutional Court is not completely out of line with the approach in other constitutional democracies.

\section{Conclusion}

The South African Bill of Rights expressly acknowledges the rights of 'all people in our country'. The state is obliged to progressively promote these rights, amongst them, the right of access to social security which applies to everyone despite the limitations of scarcity of resources and the general limitations clause. Yet, non-citizens have found themselves excluded from certain social security benefits. The Constitutional Court has extended the scope of social assistance benefits to permanent residents, but has also found that it may be reasonable to exclude certain non-citizens from these benefits. The fears of an increased burden on the current social security system and the 'welfare magnet argument' are legitimate government concerns that pose a threat to the extension of access to social security. With many adopting a 'charity should begin at home' attitude, the state is urged to respect the fundamental rights of all people within the

Art 2 of the Universal Declaration of Human Rights (1948).

See para 3.

Olivier (n 21 above) 3.

Olivier (n 21 above) 70 . 
Republic but not at the expense of the citizens of South Africa. ${ }^{67}$ The legitimacy of these fears appear to be declining with time as occurrences in both South Africa and abroad do not seem to support them.

It is clear in both South Africa and the EU that the sole requirement of citizenship for access to social security is no longer acceptable. A movement towards a more inclusive legal residence criteria is being adopted throughout Europe. The equal treatment of citizens from other SADC member states will most certainly assist in alleviating the plight of non-citizens. It will also ensure the portability of benefits and assist non-citizens in enforcing their rights. Although the EU differs from the SADC economically speaking, the principles forming the basis of the EU social security approach is sound and could assist South Africa in bringing about the necessary reforms and extension of access to social security.

Although the Khosa judgment has taken steps in the right direction it appears as though the courts in the EU have adopted a more liberal and inclusive attitude towards the position of noncitizens. Poverty and exclusion pose a threat to the rights and freedoms of many individuals. Consequently, the intervention of courts and other enforcement organisations and institutions must ensure the right to equality, human dignity and access to social security of non-citizens. Courts will also play an important role in interpreting both international and regional standards. The Constitutional Court has a duty to ensure that the values and objectives of the Constitution are upheld and legislative restrictions barring the enjoyment of social security benefits by everyone may need to be re-examined in order to ensure that the state complies with its duties under section 27 of the Constitution and international law standards. After all, charity may begin - but it certainly does not end - at home. ${ }^{68}$

67 GM Letlhokwa'Charity begins - but does not end - at home - Khosa $v$ Minister of Social Development; Mahlaule v Minister of Social Development 20046 BCLR 569 (CC)' (2005) 26 Obiter 173 \& 186.

Lethlokwa (n 67 above) 173. 